\title{
A value proposition for Open Science
}

Jonathan P. Tennant

Email: jon.tennant.2@gmail.com

IGDORE, UK

Keywords: Open Access, Open Source, Free Software, Freedom, Open Data, Social Movement https://orcid.org/0000-0001-7794-0218

Abstract: Open Science has become commonly understood in terms of its practices. Open Access, Open Data, and Open Source software are all becoming commonplace in academia. However, unlike the Free and Open Source Software movement, Open Science seems to have become largely divorced from its pluralistic philosophical and ethical foundations, which seem to have reignited from the humanities at the turn of the Millennium. To close this gap, I propose a new value-based proposition for Open Science, that is akin to the "four fundamental freedoms" of Richard Stallman that catalysed the Free Software movement. In doing so, I hope to provide a more common, unified, and human understanding to notions of openness in science.

At an Open Science Meetup at IGDORE in 2018 is the first time I ever heard someone talk about human values in Open Science. Surya Dalimunthe, a friend and colleague from Indonesia, described how we viewed openness more through a lens of justice, beauty, freedom and the quest for truth. All of the other arguments we have around openness become subsidiary once you have this solid human values-based foundation set; in fact, 'openness' in science is even enshrined in Article 27 of the United Nations Universal Declaration on Human Rights. This message resonated with me strongly, and I tried to articulate this in future talks, but could never really get my words right and found it difficult to communicate. So, like a good researcher, I decided to write a paper on it instead. This paper. 
The practical elements behind openness for the sake of increased rigour and reproducibility of science have been well-rehearsed $(1,2)$. Open Science (or Open Scholarship) includes practices such as Open Access to publications (3), Open and FAIR data (4), Free and Open Source Software (5-7), research ethics and integrity (8), responsible research (9), open research evaluation (10), Open Educational Resources (11), and multi-stakeholder engagement in research (i.e., citizen science) (12). However, none of these things are strictly values - rather, they are practices and processes that carry certain values with them implicitly. Because they are implicit, often they are more difficult to see. But that does not make them any less, er, valuable.

McGill University's Neurological Institute is the only research institute I am currently aware of that has actual real Open Science values embedded in it. These values are openness, innovation, collaboration and inclusion, transparency, accountability, efficiency, and excellence; all which still feel more based on pragmatism than anything human. Further institutional support based on 'open science values' is rare; Appendix 1 of Fabre et al. (13), calls for an Open Science Agency with "Open Science values" to bring together research needs at the European level, in particular in the context of copyright and the digital single market, as well as internationally through UNESCO. The latter initiated a consultation on Open Science in February 2020.

Because of this focus on practices and pragmatics (14), much of the discussion around the ethical and philosophical basis for openness, including its foundational values, appears to have disappeared or become diluted. While both Open Source and Open Science are often referred to as 'movements', this term is defined as "a group of people working together to advance their shared political, social, or artistic ideas"; thus, a movement is characterised by several key features: common understanding, common values, common direction, and common goals. At the present, these things remain almost completely undefined for Open Scholarship (15), and yet are a critical part of any organisational culture and its norms.

Discussions about the plural notions underpinning Open Science were there in the origins of the term $(16,17)$, but seem to have got subsequently lost in a haze. Recently, Rebecca Willen proposed that the 'Open Science community' seems to have nucleated around 3 core elements: justice, openness, and replicability. Others more cynically suggest that openness as a movement has utterly failed and should disband due to its lack of focus on justice. 


\section{Aligning openness with freedom}

In software communities, Free Software and Open Source created two distinct camps. However, for science, what if we take a different approach and consider how can freedom and openness align. Or, rather, what happens if we underpin freedom as a core value within Open Science. Based on this, here is a simple value-based proposition for putting freedom at the heart of Open Science:

1. The freedom to re-use any output of published research as you wish, for any intended purpose and without restriction;

2. The freedom to inspect the research process, and to adapt and modify it as you need (materials, data, and code are examples of prerequisites for this;

3. The freedom to redistribute copies of digital research outputs so you can help your neighbour;

4. The freedom to distribute copies of adapted research processes and outputs to others, so that whole communities can benefit from changes;

5. The freedom to participate in this process of creation and sharing, when so desired, so that scholarship becomes a truly public endeavour;

6. The freedom to acknowledge, and be acknowledged for, works contributed to;

7. The freedom to be assessed based on the intrinsic merit of research, rather than a third-party proxy or system.

Here, I consider these freedoms to be universal, shared, and unbiased within scholarly systems. This proposal is not radical, novel, and does not require much change. In fact, these might just be ways to describe what researchers are already doing in many cases. They represent the alignment of the practical rational for engaging with open research practices with the implicit and ideological aspects of this being a collective understanding of how good research should be conducted and communicated.

Based on this, anything which purports to serve 'openness', but does not fulfil these criteria, can be said to be 'open washing', or 'fauxpen'. Examples of things that restrict these things include embargo periods on research articles, or license-based restrictions around re-use. The 
value in this case of the term 'Open Science' will then increase due to its precision, as you can point directly to any research process or output and define based on its characteristic values whether it is open or not. This should be of use at the institutional and national level for implementing and monitoring the progress of Open Science policies (15).

As a natural progression from this, things which are becoming more normative within scholarly communities begin to coalesce:

1. Equal access to all outputs of scholarly research, including hardware, software, data, educational materials, and articles (14);

2. Increased participation, based on principles of inclusivity and diversity (15); and

3. More rigorous, reproducible and accountable research processes (1).

These are process- and output-based, but now based on shared, common values and understanding: That freedom is essential and intrinsic to, and enables us to meet, these goals, and catalyze further participation in research and education. Furthermore, what this also does is redefine the value of Open Science itself it related to socio-cultural values and ethics surrounding ownership of intellectual property, rather than anything purely economical (18). Thus, we agree with Leonelli et al. (19), who stated "Openness, therefore, is not only a technical problem to be solved but is also a social, cultural, and moral issue."

However, what remains absent from this is a decentralised governance structure to provide strategic coordination and oversight for meeting these goals. What is becoming clear though is that elements of this are beginning to coalesce within the 'open science community', including things such as the Open Knowledge Foundation, Open Scholarship Initiative, Wikipedia, Internet Archive, the Foundations for Open Scholarship Strategy Development, The Carpentries, as well as individual role models, such as Erin McKiernan, Alexandra Elbakyan, and Lorena Barba. These values and the individuals and organisations who uphold them should be celebrated for the liberation they enact upon our knowledge legacy as a global society.

\section{References}


1. Munafò MR, Nosek BA, Bishop DVM, Button KS, Chambers CD, Sert NP du, et al. A manifesto for reproducible science. Nature Human Behaviour. 2017 Jan;1(1):0021.

2. Masuzzo P, Martens L. Do you speak open science? Resources and tips to learn the language [Internet]. PeerJ Inc.; 2017 Jan [cited 2019 Apr 30]. Report No.: e2689v1. Available from: https://peerj.com/preprints/2689

3. Suber P. Open access [Internet]. Cambridge: MIT Press; 2007. Available from: http://mitpress.mit.edu/books/open-access

4. Wilkinson MD, Dumontier M, Aalbersberg ljJ, Appleton G, Axton M, Baak A, et al. The FAIR Guiding Principles for scientific data management and stewardship. Scientific data. 2016;3.

5. Bretthauer D. Open Source Software: A History. Published Works [Internet]. 2001 Dec 26; Available from: https://opencommons.uconn.edu/libr_pubs/7

6. Willinsky J. The unacknowledged convergence of open source, open access, and open science. First Monday [Internet]. 2005 Aug 1 [cited 2018 Dec 9];10(8). Available from: https://ojphi.org/ojs/index.php/fm/article/view/1265

7. Tennant J, Agarwal R, Baždarić K, Brassard D, Crick T, Dunleavy DJ, et al. A tale of two "opens": intersections between Free and Open Source Software and Open Scholarship [Internet]. SocArXiv; 2020 Mar [cited 2020 Mar 6]. Available from: https://osf.io/2kxq8

8. Laine $\mathrm{H}$. Open science and codes of conduct on research integrity. Informaatiotutkimus [Internet]. 2018 Dec 30 [cited 2020 Mar 8];37(4). Available from: https://journal.fi/inf/article/view/77414

9. Owen R, Macnaghten $P$, Stilgoe J. Responsible research and innovation: From science in society to science for society, with society. Sci Public Policy. 2012 Dec 1;39(6):751-60.

10. Wilsdon J, Bar-Ilan J, Frodeman R, Lex E, Peters I, Wouters PF. Next-Generation Metrics: Reponsible Metrics and Evaluation for Open Science. Report of the European Commission Expert Group on Altmetrics. 2017;

11. Wiley D. On the sustainability of open educational resource initiatives in higher education. Citeseer; 2007.

12. Bonney R, Cooper CB, Dickinson J, Kelling S, Phillips T, Rosenberg KV, et al. Citizen science: a developing tool for expanding science knowledge and scientific literacy. BioScience. 2009;59(11):977-984.

13. Fabre R, Bensoussan A, Colin L, Blanquart M, Richou L-G. The Digital Factory for Knowledge: Production and Validation of Scientific Results. John Wiley \& Sons; 2018. $132 \mathrm{p}$.

14. Fecher B, Friesike S. Open Science: One Term, Five Schools of Thought. In: Bartling S, Friesike S, editors. Opening Science: The Evolving Guide on How the Internet is Changing 
Research, Collaboration and Scholarly Publishing [Internet]. Cham: Springer International Publishing; 2014 [cited 2018 Dec 20]. p. 17-47. Available from: https://doi.org/10.1007/978-3-319-00026-8_2

15. Tennant J, Beamer JE, Bosman J, Brembs B, Chung NC, Clement G, et al. Foundations for Open Scholarship Strategy Development. 2019 Jan 31 [cited 2019 Feb 4]; Available from: https://osf.io/b4v8p

16. Şentürk R. Toward an Open Science and Society: Multiplex Relations in Language. Religion and Society Is lam Araştırmaları Dergisi [Internet]. 2001 [cited 2020 Feb 27];5. Available from: http://isamveri.org/pdfdrg/D01712/2001_6/2001_6_SENTURKR.pdf

17. David PA. The Historical Origins of "Open Science": An Essay on Patronage, Reputation and Common Agency Contracting in the Scientific Revolution. Capitalism and Society. 2008;3(2):106.

18. Levin N, Leonelli S. How Does One "Open" Science? Questions of Value in Biological Research. Science, Technology, \& Human Values. 2017 Mar 1;42(2):280-305.

19. Leonelli S, Spichtinger D, Prainsack B. Sticks and carrots: encouraging open science at its source. Geo: Geography and Environment. 2015 Jun 1;2(1):12-6. 